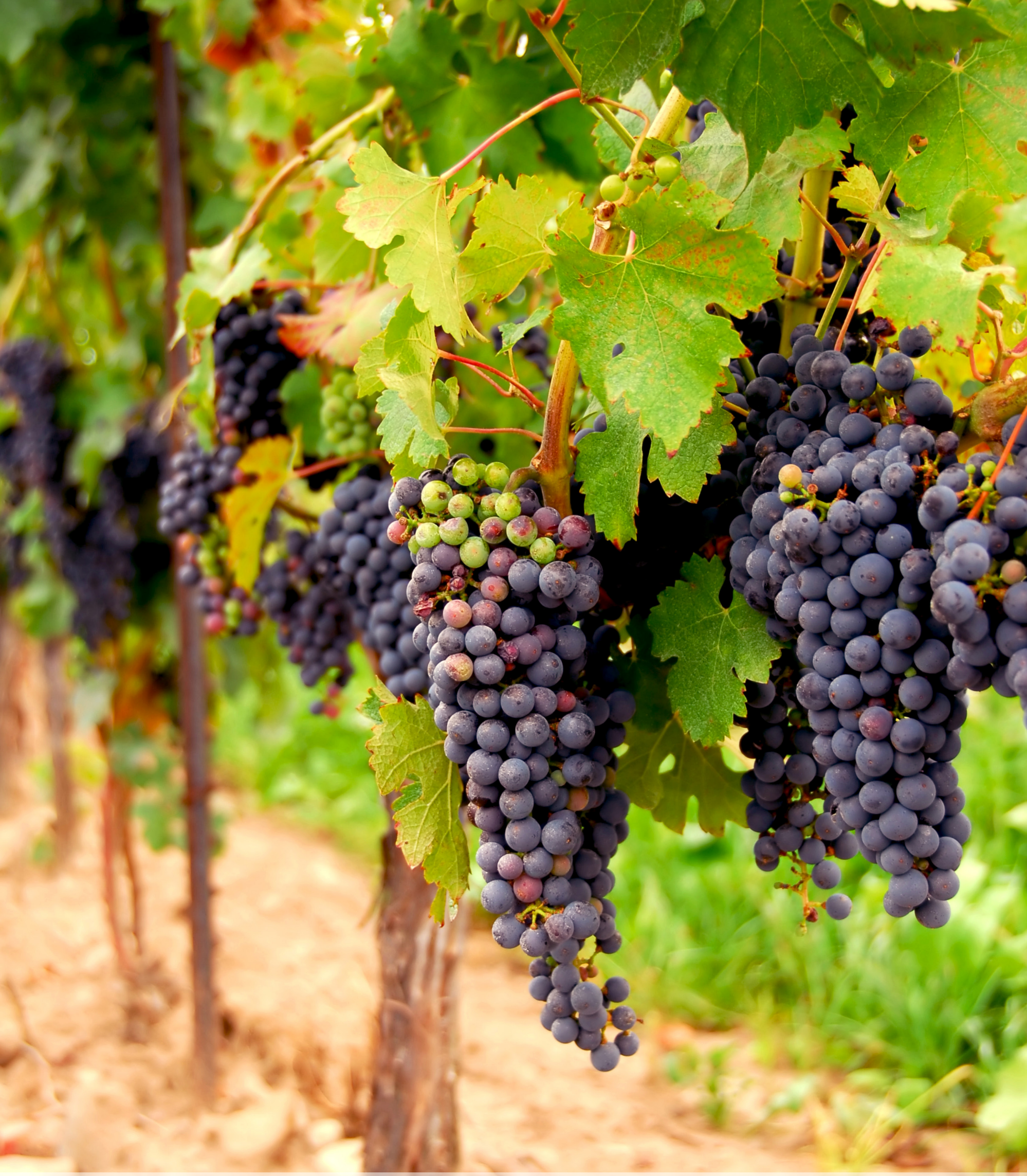

SONOMA

Wine Business Institute Wine Business Case Research Journal

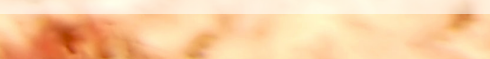




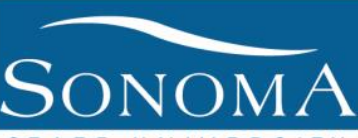

\title{
Wine Business Institute Wine Business Case Research Journal
}

Founding Editor

Armand Gilinsky

Sonoma State University

\section{Associate Editor \\ David Rowe}

France

\author{
Publication Coordinators \\ Nicole Hitchcock \\ Erin Rock \\ Sonoma State University
}

\author{
Student Editors \\ Marieshka Barton \\ Tanisha Larsen \\ Lauren Wyer \\ Sonoma State University
}

\section{Editorial Board}

\author{
Mary Barrett \\ University of Wollongong (Austalia) \\ Tatiana Bouzdine-Chameeva \\ KEDGE Business School (France) \\ Julien Cadot \\ ISG Paris (France) \\ Martha Corrales \\ ITESM (Mexico) \\ Julien Cusin \\ IAE Bordeaux (France) \\ Marc Dressler \\ Hochschule Ludwigshafen (Germany) \\ Sharon Forbes \\ Lincoln University (NZ) \\ Josep Franch \\ ESADE (Spain) \\ John Gamble \\ Texas A\&M Corpus Christi (USA) \\ Cynthia Ingols \\ Simmons College (USA) \\ J. Kay Keels \\ Carolina Coastal U. (USA)
}

\author{
Alberto Mattiacci \\ University of Rome Tre (Italy) \\ Pierre Mora \\ KEDGE Business School (France) \\ Bill Naumes \\ University of New Hampshire (USA) \\ Margaret Naumes \\ University of New Hampshire (USA) \\ Ulrich Orth \\ Kiel University (Germany) \\ Marlene M. Reed \\ Baylor University (USA) \\ Dave Rosenthal \\ Miami University of Ohio (USA) \\ Tom Ryan \\ University of Cape Town (South Africa) \\ Jeff Shay \\ Washington \& Lee University (USA) \\ Linda Swayne \\ University of North Carolina, Charlotte (USA) \\ Natalia Velikova \\ Texas Tech (USA)
}

Consulting Librarian: Paula Hammett, Sonoma State University 


\section{Wine Business Institute Wine Business Case Research Journal}

Vol. 1, No. 1

\section{Editor's Note and Industry Digest}

Welcome to the Wine Business Case Research Journal. Our mission is to provide exceptional decision-focused case studies involving real people and real events in the global wine business context. We will publish multimedia cases as well as cases in traditional document format. These cases are grounded in field research to illustrate the complex challenges that wine businesses contend with today.

\section{Who we are}

The Sonoma State University Wine Business Institute supports the production and dissemination of the WBCRJ.

Our platform is Scholastica, an open-source, open-access portal, permitting manuscript authors to have complete copyright control over their works after publication. Since the WBCRJ is an open-source, open-access journal, instructors can adopt any of these cases for classroom use, free of charge.

The WBCRJ has assembled a world-class founding Editorial Board. Members include former editors of the Case Research Journal (the world's premier case journal, affiliated with the North American Case Research Association), CASE (affiliated with the Eastern Case Research Association), Decanter (a wine trade magazine in the UK), Entrepreneurship: Theory \& Practice (cases), Wine Business Case Studies (a textbook), and International Journal of Wine Business Research. Most board members are award-winning case writers who have published in other journals. Our production coordinator, Erin Rock, and consulting librarian, Paula Hammett, are seasoned professionals who work full-time at Sonoma State University, supported by a capable editorial and production team, consisting of current Wine MBA and Wine Business Strategies undergraduate students.

\section{What the Editor looks for in a case}

The bottom line here is engagement. Instructors and students seek multimedia or written learning materials that are free (or available for a modest cost), timely, concise, supportive of learning 
goals, and unique. Classic 25+-page strategy cases that begin with a middle-aged white male pondering a decision while gazing out a window may well have gone the way of the dodo bird. Engaging students to start a discussion in any class is always a challenge. Part of our role as instructors is to give students "something to talk about." 1

The same logic applies to the guidance we supply to prospective case authors:

(1) Value - Your case should be of great value relative to the price - which happens to be free, as this is an open-source, open-access journal.

(2) Uniqueness - Your case should be in a timely, i.e. in a contemporary setting although the issues and hypotheses and theories to be applied may necessarily be timeless in nature.

(3) Purpose - Your case should be decision-focused in order to support stated learning objectives - in a wine business or related course and directed to a specified level of learning.

(4) Impulse - Your case should be unique or fill an as yet unmet pedagogical need — its contribution to the field of wine business research must be crystal clear.

\section{Cases in our inaugural issue}

We have selected five outstanding cases that reflect a diversity of topics and regions and that represent a diversity of viewpoints regarding the current state of wine business research and practice. They are: Lindsey M. Higgins, Michael H. Lau, and Jean Dodson Peterson's, “Risky Business: Creating a Super Luxury Estate Brand”; Michael Braun and Bambi Douma’s, "Podere Riosto: A Forchetta in the Road”; Stephen Cox’s, “A Local Pub”; Mary Barrrett, Luca Gottardi, and Ken Moores' "Planning in the Poncini Family Business"; and Raymond H. Lopez's, "Sula Vineyards (B)." For ease of reference, the cases are summarized in the table, "Industry Digest for Volume 1, Number 1.” If you are interested in obtaining the instructor's manuals (also known as teaching notes) from case authors, we ask that you contact them directly.

\footnotetext{
${ }^{1}$ Which brings to mind the song "Something to Talk About," written by Shirley Elkhard, which became a hit for Bonnie Raitt in 1991.
} 
Industry Digest for Volume 1, Number 1 (Spring 2016)

\begin{tabular}{|c|c|c|c|}
\hline Case / author(s) / contact info & $\begin{array}{l}\text { Company/ } \\
\text { location (year) }\end{array}$ & Challenge(s) & Contribution(s) to learning \\
\hline $\begin{array}{l}\text { Risky Business: } \\
\text { Building A Super Luxury Wine Brand } \\
\text { Lindsey M. Higgins, Jean Dodson } \\
\text { Peterson, and Michael H. Lau } \\
\text { *, California Polytechnic, San Luis Obispo } \\
\text { lhiggins@calpoly.edu }\end{array}$ & $\begin{array}{l}\text { ARA Vineyards } \\
\text { (disguised), } \\
\text { Howell Mountain, } \\
\text { Napa, California, } \\
\text { USA (2016) }\end{array}$ & $\begin{array}{l}\text { Price changes have costs; } \\
\text { what are the costs associated } \\
\text { with updating wine release } \\
\text { prices and how will on- } \\
\text { premises and DTC channels } \\
\text { respond? }\end{array}$ & $\begin{array}{l}\text { Illustrate wine luxury branding and } \\
\text { promotion; evaluate "sticky" pricing and } \\
\text { distribution channels; predict how wine club } \\
\text { members will react to price changes. }\end{array}$ \\
\hline $\begin{array}{l}\text { Podere Riosto: A “Forchetta” in the } \\
\text { Road } \\
\text { Michael Braun* and Bambi Douma, } \\
\text { University of Montana } \\
\text { Michael.braun@business.umt.edu }\end{array}$ & $\begin{array}{l}\text { Podere Riosto, } \\
\text { Emilia-Romagna, } \\
\text { Italy (2012) }\end{array}$ & $\begin{array}{l}\text { How can a small family- } \\
\text { owned business plan for } \\
\text { succession despite strife and } \\
\text { economic uncertainty? }\end{array}$ & $\begin{array}{l}\text { Understand complexity in a family wine } \\
\text { business during a time of transition; evaluate } \\
\text { impact of diversification on business model. }\end{array}$ \\
\hline $\begin{array}{l}\text { A Local Pub Tries To Keep Up with } \\
\text { Changing Preferences } \\
\text { Steven Cox* and Jim Foster, Queens } \\
\text { University of Charlotte, North Carolina } \\
\text { coxs@queens.edu }\end{array}$ & $\begin{array}{l}\text { Selwyn Pub, } \\
\text { Charlotte, NC } \\
\text { (2014) }\end{array}$ & $\begin{array}{l}\text { What is the impact of } \\
\text { expanding the wine list to } \\
\text { include new, unfamiliar } \\
\text { brands on customers and } \\
\text { staff? }\end{array}$ & $\begin{array}{l}\text { Identify revenues vs. contribution margins } \\
\text { for each beverage category; apply Ansoff's } \\
\text { Product Combination Matrix to product } \\
\text { portfolio; evaluate options to train and } \\
\text { motivate staff to enhance wine sales. }\end{array}$ \\
\hline $\begin{array}{l}\text { Planning in the Poncini Family Business } \\
\text { Mary Barrett*, University of Woolongong, } \\
\text { Australia } \\
\text { Luca Gottardi, and Ken Moores, Bond } \\
\text { University, Australia } \\
\text { mbarrett@uow.edu.au }\end{array}$ & $\begin{array}{l}\text { Poncini e Santoro } \\
\text { Azienda Agricola, } \\
\text { Trento, Italy } \\
\text { (2015) }\end{array}$ & $\begin{array}{l}\text { Should the Poncinis remain } \\
\text { in the wine industry, and } \\
\text { how to make this decision? }\end{array}$ & $\begin{array}{l}\text { Illustrate strategic planning processes for a } \\
\text { family business; apply the concept of } \\
\text { "liability of newness" to a wine business; } \\
\text { recommend ways to reach a consensus on } \\
\text { future direction. }\end{array}$ \\
\hline $\begin{array}{l}\text { Sula Vineyards (B): Sustainable Growth } \\
\text { Raymond H. Lopez*, Pace University, } \\
\text { New York } \\
\text { rlopez@pace.edu }\end{array}$ & $\begin{array}{l}\text { Sula Vineyards, } \\
\text { Nashik, India } \\
\text { (2013) }\end{array}$ & $\begin{array}{l}\text { How can Sula finance } \\
\text { growth and maintain } \\
\text { operating control of the } \\
\text { company, despite persistent } \\
\text { negative cash flows? }\end{array}$ & $\begin{array}{l}\text { Understand the Indian wine industry; apply } \\
\text { tools and techniques for financial analysis, } \\
\text { working capital, cost of capital, optimizing } \\
\text { capital structure, and pro forma forecasting; } \\
\text { evaluate pros \& cons of diversification into } \\
\text { hospitality / tourism. }\end{array}$ \\
\hline
\end{tabular}

*Contact person

Special thanks to the thirteen expert reviewers (listed below), who provided developmental feedback to case authors - with an average review return cycle of 23.9 days - during multiple stages of review:

Julien Cadot, ISG Paris

Julien Cusin, IAE - Bordeaux

Marc Dressler, Hochschule Ludwigshafen

Sharon Forbes, Lincoln U.

Nicole Hitchcock, J Wines, founding Assistant Editor

Margaret Naumes, U. of New Hampshire

William Naumes, U. of New Hampshire

Marlene M. Reed, Baylor U.

David Rosenthal, Miami U. of Ohio

David Rowe, Associate Editor

Tom Ryan, U. of Cape Town

Linda Swayne, U. North Carolina, Charlotte

Natalia Velikova, Texas Tech / Texas Wine Marketing Institute 
We plan to publish two issues per calendar year, so keep an eye out for Volume 1, Number 2, to be published in Fall 2016.

For information on submitting your case, go to:

www.sonoma.edu/sbe/wine-business-institute/wine-business-case-journal.

Our Scholastica case submission portal can be found

at: https://submissions.scholasticahq.com/sites/wine-business-case-research-journal.

We welcome your feedback on how to improve our journal, so feel free to contact me at the address below. Enjoy our journal.

Very truly yours,

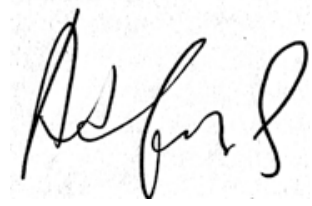

Armand Gilinsky

Founding Editor, Wine Business Case Research Journal

Sonoma State University Wine Business Institute

wbizcase@sonoma.edu 